\title{
Walking in the light: reflections on screendance in a time of pandemic \\ Katrina McPherson
}

Keywords: Lockdown, Edinburgh, screendance, Solnit, Tarkovsky, Alston, Blaze, Zoom, EXPORT, Laing, Mekas

This essay was written within the first few weeks of 'lockdown', which came into effect in Scotland on 23 March 2020, in response to the spread of COVID19. The rules were that no one was allowed to leave their home, unless for essential journeys, or for 1 hour of recreation outside per day, or to travel more than 5 miles from home.

Restricting where we can go seems to focus us on where we are. Living now, back in the city where I grew up, on my evening walks I experience the built-environment as I would have as a child and teenager - on foot. I tramp the streets, sometimes alone, often with a daughter, usually with the wee dog, but always detouring approaching strangers, familiar faces, neighbours with a smile, a shrug, an acknowledgement that this is our new reality, one which we are trying to normalise, yet at the same time are determined to believe won't always be so. At walking pace (I'm no jogger, and cycling the route seems to be over too quickly to make the most of our time allowed outside), the details of this grand city's architecture process by in sharp relief, exquisitely lit by the golden beams of a setting Northern summer sun, and crystal clear in the newly fresh, pollutantlite air. Grand town villas, with carefully tended rambling gardens; Victorian tenements (now much sought-after family homes); 1970s blocks; half-built re-imagined public buildings, their transformation into condos halted in mid-air by social distancing restrictions, all pique my interest, yet not enough to halt the flow of my journey. The lack of drama and the pace of travel allows my mind to come back into my body, to become conscious of my walking, my head balanced on my spine, my feet peeling off the tarmac, my arms swinging gently, my hands curled and relaxed.

It strikes me that what I am experiencing through living in 'lockdown' and the limits imposed on where we can travel, shares aspects in common with the time when many of the buildings that I am walking past were built. Back at home, I google 'images of Edwardian Edinburgh' and, sure enough, I see scenes, captured over a 100 years ago, that resemble the streets outside my window today: people walking along pavements and spilling onto roadways, going about their every-day business, many others seeming less purposeful, a few blurred bicycles, and the occasional car, open-topped and revealing important-looking, well-dressed passengers. In late 19th century Scotland, there were horse-drawn trams instead of our empty busses and it strikes me that I have not seen, or heard, an aeroplane for weeks. These photographed people are not going

The International Journal of Screendance 11 (2020). https://doi.org/10.18061/ijsd.v11i0.7822

( $) 2020$ McPherson. This article is published under a Creative Commons Attribution 4.0

International License (https://creativecommons.org/licenses/by/4.0/) 
to fly off to a far-away country and only the wealthiest amongst them could dream of boarding a train and steaming up to holiday destinations in the Highlands. The majority were going to walk and see and experience the world through their bodies, at pedestrian speed, in the time and the space that they live, as I am doing now.

In Rivers of Shadows - Eadweard Muybridge and the Technological Wild West, American philosopher and social commentator Rebecca Solnit writes about the era of the invention of the telephone and phonograph and describes how these "were added to photography, telegraphy and the railroad as instruments for 'annihilating time and space'...", attributing them as having launched 'the modern world, the world we live in...". ${ }^{1}$

These inventions, some of which carried our bodies and belongings, others our words and images, acted to shrink the space between things, and in doing so, sped up, fragmented and transposed the time it takes to travel between them. Following hard on their heels, and combining newly invented mechanics and optics with the desire to capture and (re) create movement, the first film camera/ projectors, and their closest relatives, would further and completely alter our experience of the environment we inhabit and, as Solnit describes, our relationship to time spent in it:

And motion pictures changed the relationship to time further; they made it possible to step in the same river twice, to see not just the images but events that happened in other times and other places, almost to stop living where you were and start living in other places or other times. (my emphasis) ${ }^{2}$

Re-visiting this idea in the context of the lock-down life, it assumes a new resonance. My enforced walking has shown me how little of my life is usually spent at this pace, and how deeply enmeshed this time and space/speed altering has become in our experience of the world.

At the end of my excursions, I come back into the flat and flip open the laptop. A portal into an on-line world that is a direct descendant to those early flickering experiments in space and time altering. And yet, whilst perhaps sharing DNA with early film, that small portable screen feels more complex, multi-layered, fraught, bound up in economics and financial, physical and mental well-being. But perhaps not? Later in the first chapter of Rivers of Shadows, Solnit describes the rapid evolution of moving image culture into cinema and, in her words, I recognise much that is applicable to what is offered by the on-line world: 
Movies became a huge industry, became how people envisioned themselves and the world, defined what they desired and what was desirable. The Russian film director Andrei Tarkovsky thought that time itself, 'time lost or spent or not yet had', was what people desired and fed upon in the films that became a collective dream world inhabited by multitudes. ${ }^{3}$

'time lost or spent or not yet had'

Time not experienced in the moment.

Time not experienced at walking pace.

Time on the Internet.

Time in the Internet.

Time spent planning for things that don't happen.

Time spent thinking about things that never happened.

Time spent walking.

There is no doubt for me that my privileges have continued into lockdown. Like many self-employed artists, my income stream was initially devastated, as paid gigs due to happen fell away and it was not at all clear when or how they could return. But having unlimited access to the Internet has meant that my work can be re-channelled and, a few weeks in, my diary is filled with on-line workshops to teach, films to edit, presentations to deliver and artists to mentor, all from my laptop perched on a table in a corner of the flat. It is not so easy for others. Pandemics seem to highlight the inequalities, the flaws in the flaws of our structures. It's extremely humbling. It also feels a bit weird to be thinking and writing about art-making when so many people are experiencing hardship, or working so bravely and intensely to care for those people whose lives are directly endangered by the pandemic. But that has always been the way with art. It can seem too unimportant. However, I for one have never lost hold of the belief that it is also too important to let slip. If I am not trained to work on the front-line, at least I can try to use my expertise and experience to make a different sort of contribution.

I've always enjoyed Douglas Rosenberg's description of screendance as "perhaps the most invasive of all arts species" and his suggestion that, whilst seemingly a newish art 
form, it has in fact been there all the time, simply "hiding in plain site'. ${ }^{4}$ Through this play on words that links ideas of visibility and place, in an unpublished talk that he gave at Stanford University, Rosenberg conjures an image of screendance as a surreptitious art-form, one that existed "before there was a critical mass of interest in the form, even before it was named as such." ${ }^{15}$

An unexpected legacy of the 2020 COVID-19 pandemic may be that screendance becomes more visible, shifting if not into the limelight, then perhaps at least out of the shadows? Certainly, I have seen evidence of this in terms of the numbers of people interested in learning about the form. Early in the global pandemic, there were over 60 applicants in a matter of days for my screendance workshop offered on-line. Artists reaching out to participate from Argentina, Chile, Germany, Russian, the USA, Scotland, England, telling on their application forms how they had found themselves at home, away from their usual creative spaces and collaborators, with time on their hands, due to other work and activities being cancelled, and thinking pragmatically now about how they might make, share, sell and imagine dance, movement, performance, on screen and in contexts other than live events.

An appearance of screendance bang in the middle of the UK mainstream came recently when veteran English choreographer Richard Alston wrote a piece for the Guardian newspaper, in which he describes his re-watching the screen-versions of his choreography whilst in lock-down. Over the years, these films had been directed by people who evidently understood the power of well-made screendance, whether it was being recognised at the time or not. As Alston observes:

I'm beginning to understand how exhilarating can be the marriage of a moving camera and dancers flying by. It's made me seriously think about whether the speed and detail which I so love in dance does indeed come across more clearly with good camerawork and sensitive use of totally engaging close-ups - and more engagingly perhaps than on stage. ${ }^{6}$

You got it!

A frequent hiding place for screendance are music videos, and one which I have been drawn to time and again, particularly during this time of physical distancing, is Territory, by the French electronic duo the Blaze. ${ }^{7}$ Cousins and creative collaborators, the Blaze have rightly been lauded not just for their dreamy beats, but also for the richly human intensity of the short films that they make to accompany their music. Through the lens of an embodied, empathetic camera, in Territorywe witness the return of a young male boxer to his family home in an Algerian city. The gently handheld camera moves with and around the young man as brothers, parents, grandparents, siblings and cousins envelop their cherished-one back into their arms and the family home. Seen at 
unflinching close proximity, we feel the intensity of joy and familiar love as he breaks down in tears, his face scrunching, body crumpling as he is engulfed in their relieved joyful embraces.

Talking about Territory in an interview published in the New York Times in 2018, filmdirector Barry Jenkins describes the experience of being blown away on first seeing the work, likening the images of male vulnerability, as framed by the Blaze's moving camera, to dance:

It's almost like a ballet in a certain way, the camera is so active. It's participating in this dance. ${ }^{8}$

There is no dialogue, no backstory, no explaining in Territory, and the camera never breaks its gaze, as we at first struggle to read the man's emotion, before being engulfed in shared relief and comfort. Watching now, in the context of the current physical distancing restrictions, this has become almost unbearable, an intense reminder of how something as essential to life as proximity and touch feels so much more dangerous now.

In my family circle, like so many others who have the possibility, weekly gatherings and quiz nights on Zoom have become a thing during lockdown. As children, parents, cousins, brothers, sisters, aunts and uncles gather opposite each other, watching each other watching each other through the portal of the computer screen, I am reminded of Facing a Family by the pioneer Austrian video artist Valie EXPORT. ${ }^{9}$

This seminal work was made for television in 1971. It consists of images of a man, a woman and two children sitting at a dinner table, apparently filmed from the point of view of the television set that they are watching as they eat. The family's gaze is drawn again and again towards the TV (and thus the viewer), as EXPORT highlights the pervasiveness of the screen-object in our lives. By watching the family watch us, their banal interactions - and the vacancies around them - are exposed and, viewing this on the television for which is was conceived, our own behaviour is mirrored. EXPORT further draws our attention to the incessant flow of TV images by disrupting them through freeze frames, further strengthening the comparison to our current experience of the screen in our living space.

I have always been drawn to art that illuminates, and critiques, the medium by which it comes into being. I wonder what will be the work that we make now, and in the future, 
that shines a light on the virtual architectures of our current lives, like EXPORT does in her work, and the sunlight does to the old buildings on my street walks?

Sunlight is an image that used by the writer and critic Olivia Laing in her latest book Funny Weather - Art in an Emergency, the pages of which have become a refuge, and place of mentorship and inspiration for me in these past few weeks. In it, Laing writes about coming across an Instagram post announcing the death of Jonas Mekas, which quoted from his 2007 gallery project To New York with Love. She retells how one of the stills had a caption that read: "YOU LOOK AT THE SUN. THEN YOU RETURN HOME AND YOU CAN'T WORK. YOU'RE IMPREGNATED WITH ALL THAT LIGHT."10

Laing connects this image with an observation of the importance - the function, if you like - of art, by likening Mekas' experience of being filled with sunlight to the essential nature of what art offers us, when she writes:

'We are so often told that art can't really change anything. But I think it can. It shapes our ethical landscapes; it opens us to the interior lives of others. It is a training ground for possibility. It makes plain equalities, and it offers other ways of living. Don't you want it, to be impregnate with all that light? And what will happen if you are?"11

At a time when it would be too easy to down tools, to feel overwhelmed by the complexities of navigating the changes, to feel that making/sharing/talking about art, and encouraging others to do the same, with and alongside you, is pointless and irrelevant, I am finding it infinitely helpful to meditate and work with the processes that Laing describes so simply. At time when less must become the norm, these few sentences are more than enough of a manifesto for moving forward. And that is also important. Art as described by Laing is a process, not a product. It's how it moves towards, around, between and in us that is essential. Like the sun.

\section{Author biography}

Katrina McPherson is a director and award-winning screendance artist whose creative, scholarly and educational practice is at the forefront of the international

field. www.katrinamcpherson.com; www.makingvideodance.com 


\section{References}

Alston, Richard. "Move on up! The most joyful dance clips to raise the spirits." The Guardian. May 14, 2020. Accessed online. https://www.theguardian.com/stage/2020/may/14/move-on-up-the-mostjoyful-dance-clips-to-raise-the-spirits

Barry Jenkins quoted in "How the Blaze's Emotional Dance Music Brings Listeners to Tears"Caramanica, Jon. New York Times, Aug. 16, 2018.

Accessed online. https://www.nytimes.com/2018/08/16/arts/music/the-blaze-dancehall.html

Facing a Family. Valie EXPORT. Austria: ORF TV. 1971.

http://www.medienkunstnetz.de/works/facing-a-family/video/1/

Laing, Olivia. Funny Weather: Art in an Emergency. London: Picador, 2020.

Rosenberg, Douglas. Hiding in Plain Site. Notes for a public lecture given at Stanford University, November 2018. (unpublished)

Solnit, Rebecca. River of Shadows: Eadweard Muybridge and the Technological Wild West. New York: Penguin Books, 2003.

Territory, (2017). The Blaze. YouTube. https://www.youtube.com/watch?v=54fea7wuV6s

To New York With Love. Jonas Mekas. USA. 2007 https://www.artspace.com/jonas_mekas/to-new-yorkwith-love

Notes

${ }^{1}$ Solnit, 4

${ }^{2}$ Ibid., 4

${ }^{3}$ Ibid., 4

${ }^{4}$ Rosenberg

${ }^{5}$ Ibid.

${ }^{6}$ Alston

${ }^{7}$ The Blaze

${ }^{8}$ Jenkins

${ }^{9}$ EXPORT, 1971

${ }^{10}$ Laing, 8

${ }^{11}$ Ibid., 8 